\title{
Analysis of Reading Comprehension Levels of Fifth Grade Students Who Learned to Read and Write with the Sentence Method
}

\author{
Muhittin Sağirli \\ Correspondence: Muhittin Sağirli, Marmara University, Atatürk Faculty of Education, Turkey
}

Received: October 8, 2015 Accepted: October 19, 2015 Online Published: November 9, 2015

doi:10.11114/jets.v4i2.1122 URL: http://dx.doi.org/10.11114/jets.v4i2.1122

\begin{abstract}
The purpose of this study is the determination of reading comprehension levels of fifth grade's students who learned to read and write with the sentence method. With the program of 2005, it has been amended in the first reading and writing method. In the teaching of first reading and writing, it was passed to the sentence method instead of sound based sentence method. Fifth grade students in this study can be considered as the last group of students who learned first reading and writing with the sentence method. This research carried out by the group who is a total of 1000 students who studying in the primary schools in Üsküdar, Kadıköy, Ataşehir, Ümraniye, Bahçelievler, Bayrampaşa in İstanbul. Both quantitative and qualitative methods were used in this study. The application of research has been done in the 2008-2009 academic year. Achievement Test which developed by researchers were applied to fifth grade students in the elementary school. The test consist of a total of 15 questions. 10 of the questions are multiple-choice questions (closed-end) and 5 of the questions are open-ended questions. The open-ended questions were applied to 50 students who randomly selected students from thousand students. The percent of correct answer to 10 multiple-choice questions of students is $77,12 \%$. The percent of wrong answer is $22,09 \%$. The percent of blank answer is $0,79 \%$. The percent of correct answer to 5 open-ended questions of students is $34 \%$. The percent of wrong answer is $32,4 \%$. The percent of blank answer is $34,4 \%$. In terms of students' reading comprehension skills, it is seen to be more successful multiple-choice questions than open-ended questions.
\end{abstract}

Keywords: sentence method, teaching of first reading and writing, comprehension of reading, fifth-grade, elementary school

\section{Introduction}

Generally judging by reading recipes, you can conclude the following in common: Reading, the word who is perceived is passed through a mental process. Reading should include comprehension, understanding, interpretation and thinking. The reasoning process is the most dominant aspect of reading. Reading is interpreted symbols in a meaningful way and is an estimate psycholinguistics. Reading is a mechanism closely related to the senses, especially the sense of sight. Reading is the first step on the road to learning. It is a knob of the door opening to the known from unknown. It is draws the flow of life, shaping your future, enables us to understand the history and is waiting to be solved cryptic treasure which hidden feet allowed in the mind, language and heart. Reading, enhance individual enlightenment. It increases academic knowledge, expands the general culture, provides socialization. It has an important place in the learning of ethical values, in the raising the level of moral and the winning aesthetics. Reading is the most effective communication tool which is used throughout life, starting from the first class -average of five years-. Information is an effective way to develop skills. Mental abilities such as comprehension, understanding, interpretation, judgment, analysis-synthesis making, assessment are developed with accurate, fast and continuous acquisition of reading skills. Life and civilization, largely based on the success of individual in the reading and writing. Reading, is one of the main sources which is feeding and improving the idea. To become aware of the individual's individuality depend on the winning of the reading power (Özdemir, 1983). Recognize words, to find the meaning of words to comprehend or to interpret the reading material, read quiet with the appropriate speed reading for purpose of reading and material, read aloud, read books effective, get pleasure from reading, reading to develop the ability to use to meet individual interests and needs, to maintain rich and varied experiences through reading, improve continuous reading interests, to understand current events, meet needs and requirements, intellectual needs, improve themselves, meeting individual and social requests and a hobby type of struggle can be ranked among the purposes of reading (Kayalan, 1997). The "first literacy" is used to period which children can read aloud the signs of written language, can say, what was said or wrote to express their thoughts. This 
period includes which from oral language to wrote language until period of quiet reading.

Reading comprehension is one of the most important indicators of reading success. It can be obtain an idea of a student's comprehension skills by way of explaining read (Akyol et all., 2014:14). The vocabulary has a very large effect to understand read. To enrich the vocabulary of students, as well as it should be taught ways to capture tips that provide an estimate of the concepts in the texts which they read (Çiftçi and Temizyürek, 2008; 126). If the reading activity results comprehension, it carries a value. Reading comprehension is one of the most important variables that impact on learning of student. Efforts which individuals show to understand read can be listed as analysis of the structure of text, understand the content of the text and interpretation, criticism of the text. Each text has a structural integrity. Vision and determination of this unity constitutes one of the main aspects of reading and comprehension. The people who read the text which is a linguistic product needs to able to take complete transmission of messages that the author, recognize good linguistic units that bears his message and understanding; finding issues and identification. Read action is a kind of conversation reader between the person who created the text. We can agree or can disagree some ideas of author in the text. So, knowledge and experience of reader are not identical the author's. The activity of thinking on a text which read, carrying a weight read are critizing the text (Tazebay, 1997).

It is located on the basis of education and training in relation to read and understand. Individuals who can establish this relationship can achieve success in the academic sense. Reading skills such as comprehension skills are activity that can be also developed. First reading and writing were taught using the sentence method in our country for many years. The sound based sentence method was adopted as compulsory and only method of first reading and writing in all country from 2005 - 2006. Pilot implementation was started in the 2004-2005 academic year. The method which was used only in the laboratory school curriculum was introduced in the whole country next year. It must not be forgotten the fact that is a close relationship in the teaching of first reading and writing between comprehension. First reading and writing is to create a new channel of communication and interaction by teaching symbols which humanity create ten thousand years. Education realizes a great miracle by comprehend this article that has been developed ten thousand years by humanity, to child who is seven-years-old in a time of seven to eight months (Güleryüz, 2000, s.2). Teaching of first reading and writing should not be considered as a activity which is one dimensional and is gained reading techniques only. Such an attitude tears off early literacy activities from the other language activities. The goal of teaching of first reading and writing should not be to gain reading and writing skills only. It is expected the boy who won the literacy skills, but also fast, accurate reading and understanding; to enjoy reading and to develop a functional writing skills (Çelenk, 2007, s.14).

In the new program, it was applied sentence method instead Sound Based Sentence Method for the first literacy teaching and letters italic text were adopted in the teaching of writing. In this method,it is started to the first literacy teaching with sound. After a few sounds to create a meaningful whole; the syllable words and sentence from sounds are reached. It is follwed a way to whole from parts.It is given Others for basic text, nor any attainment in reading nor writing size; other basic text any information when or how to be taught. In the previous program, the sentence method is adopted in the teaching of first reading and writing; the basic text is adopted in the teaching of writing. It is given italic text in the second year. The most striking difference new programs between the previous program is the recommended method for teaching reading and writing and is the recommended format for the writing. The appropiate environments should be established for children at a very early age, to increase their sensitivity to sounds, syllables ensure the detection, improve their vocabulary, improve comprehension skills, to help them gain the confidence to communicate attitude. In particular, the program of preschool education institutions, and it should be included these features related to gains and the learning situation; the children must start enough ready to process of free reading and writing. In our country, expansion of pre-school education, is very important in this context.

Understanding to read is measured with the questions. Science reveals itself to explain philosophy of existence with various questions and produce solutions to problem situations. Everything begins with curiosity and questions. The most important factor is questions in step into from the unknown world to awareness. Given the educational dimension, the questions have power to, carry out the work of measurement and assessment, strengthen the existing information by identifying the shortcomings. The question should be put forward to reveale to infer or not to infer to reading activity (Ünal and Köksal, 2007).

Questions can be used to determine assessment of learning, recognition and placement of student, soundness of the curriculum, the effectiveness of educational services in the process of assessment and evaluation (Demirel, 2002).

Right and wrong test, matching item, multiple-choice tests, classic essay, short answer tests. Short answer tests which are used in the measure and evaluation the academic status are also used in the understanding to read. The most commonly used tools are the classic type open-ended essay and multiple choice tests to measure and the evaluation of reading comprehension skills in schools (Temizkan and Sallabaş, 2011).

The students must use various strategies to improve the reading comprehension skills in before reading, during and after. 
Before reading, removal of things that distribute attention, accentuation of headings and subheadings, making estimation, during the reading, taking notes on the text and the description text with notes, underline of key words and description of these words, after reading, marking key concepts in the question, taking note that what is asked and proving the correct answer must be used (Castilleja, 2011; akt. Ekiz et all; 2012).

By Akyol (2010), skimming, rendering intent for reading, and to bring to preliminary information in the environment of reading, making predictions are activities that can be done before read. Fluently reading, checking understanding, using help strategies are activities that can be done during reading. Summarization and evaluation of read are activities that can be done after reading.

Examining the articles in this field, the articles which research the effects of methods on the success of fifth grade students in the teaching of first literacy (reading and writing) were found. (Vatansever, 2008; Şahin, 2011; Kuşdemir Kayıran and Karabay, 2012) By Vatansever (2008), the general success scores of students who learn first reading and writing with the sound based sentence method are more successful than the general success score of students who learn first reading and writing with the sentence method. Şahin (2011) and Kuşdemir Kayıran and Karabay (2012) haven’t found the significant difference in the success of reading comprehension of students who learn to first reading and writing with different methods.

Based on the views of teachers, it has been reached the result to prefer the sentence method instead the sound based sentence method in the studies which research the effects of the sound based sentence method and the sentence method on the reading comprehension (Tok, Tok and Mazı, 2008; Turan and Akpınar, 2008; Kadığlu, 2012).

It was not founded to have a significant impact of the variable of the types of learning, class, age, gender on the skills of reading comprehension in the studies which research the factors affecting to reading comprehension (Kutluca Canbulat, 2013; Erginer, 2014; Ürün Karahan, 2015; Soysal, 2015; Kutlu and friends, 2011).By this study, the characteristics of students,the method used,teacher and material of course affect to meaningful reading as the whole.It is reached the result to have positive effects of the speed reading techniques on the reading comprehension of fifth grade students. The number of student's books, the number of books in the home, the teacher to print summary about reading the text, the teacher to give homework about read have a significant effect on the success of the reading comprehension of students.

It is reached the result to develop the reading comprehension skills using learning strategies in the studies which research to the strategies of reading comprehension, learning and understanding (Aktaş, 2015; Yılmaz, 2008; Belet ve Yaşar, 2007; Taşdemir, 2010).Also there is a positive relationship between the level of understanding strategies and the academic achievement.

It has been found the studies that research understanding skills of students in this field. Işık (2014), Topuzkanamış ve Maltepe (2010) have expressed that the level of reading comprehension teachers candidates is less than average. Özder Konedralı and Doğan (2012) have expressed that the fifth grade students showed the lowest success in terms of sentence. Çiftçi and Temizyürek (2008) researched the level of Access of fifth grade students to the gains related to reading comprehension that are in the program of Turkish Education and they have found the achievement score as $84,56 \%$.

The achievement of students that is in the multiple-choice questions is higher than open -ended questions in terms of level of reading comprehension in the survey that has been done on measurement of reading comprehension (Temizkan and Sallabaş, 2011).

In this paper, the research is done with fifth class students. Because these students' class is a passing class from primary school to secondary school. It is the last class for primary teachers. For primary school education academics the fifth class is ideal. Because of its highest understanding studies done these level. And the paper is original. İn the literature there wasn't any study which investigated the relation with initial literacy methods and about further reading comprehension tasks. In Turkey to 2004 the initial literacy was learned by sentence method. After 2004 the programme is changed. And then altogether first class teachers have to use sound-based reading and writing method. This paper is important for measuring about reading writing methods effects on reading comprehension.

The purpose of study;

1. What is level of reading comprehension of fifth grade students who learned firft readin and writing with the sentence method?

\section{Method}

Mixed methods research design is a process that is used data collection in research, analyze and both quantitative and qualitative methods for blending (Creswell, 2012). The quantitative research methods were used to determine the level of fifth grade students' reading comprehension. It was studied with a group (1000 students) who learned first reading and 
writing with the sentence method.10 multiple-choice questions were applied to thousand students.5 open-ended questions were asked to fifty students who selected randomly from thousand students. The review of literature started after the problem of study is determined. Researcher has done the review of literature until the end of the reporting period. The studies of reliability and validity of data collection tools were done by the researcher himself. The application pilot was made in any school which isn't the application school (Esenler).The application has been started after the necessary corrections were made. Data were analyzed and organized after statistical process ended. While these operations were continuing, reporting was made. This application continued for two months.

The population of this study is fifth grade students who learned first reading and writing with the sentence method. The working group of study is 1000 students who are studying in the elementary school in İstanbul (Üsküdar, Kadıköy, Maltepe and Ümraniye, Bahçelievler, Bayrampaşa). Due to the last students who learns first reading and writing with sentence methode are fifth grade students, it is important that the study needs to be done this year. Working group students according to gender distribution is as follows:

$57 \%$ girls (570), $43 \%$ male (430) of students who learned first readin and writing with sentence analysis method is made up of students.

The success test which is developed for determination of level of reading comprehension of students making corrections as a result of the front application. The test is developed from an anonymous story for the purpose of the research; have been created with the opinions of two Turkish teacher, three fifth-grade teacher, one primary school inspector and two experts. "Thousand Mirror Mountain" which is an anonymus text was applied as achievement test. The measurement tool which was prepared as a draft was applied to 30 students who selected randomly in the school in Esenler (İstanbul). Each of the test substances was made the analysis substance a result of this preliminary. The insufficient questions were removed from the measuring tool. It has been made arrangements in a question. A result of this process, Cronbach's alpha coefficient was calculated as 0.672 . Instructions have been created for practitioners in front of the achievement test because the application is done by teachers. It was given the final form to the achievement test which included 10 multiple-choice questions and 5 open-ended questions a result of the pilot application. The test which was given the final form was applied to students in equal time-during a course- on successive days. The questions which were answered as right and wrong by each students were determined. Amendment forms are applied. The arithmetic average of the scores which were taken by each students in the first and second has set exact data. The responses of students were used to prepare the answer key of the achievement test's open-ended questions. While the text was preparing, the length of the sentence, the known and the unknown status of the meaning of words, the semantics of the text is sure to match the level of fifth grade students. Student's vocabulary is also taken into account.

The datas were obtained from a total of 1000 students who were studying in İstanbul (Üsküdar, Kadıköy, Ataşehir, Ümraniye, Bahçelievler, Bayrampaşa) in the quantitative part of the survey. The qualitative part of the research is datas which were applied from 5 open-ended questions which were applied to 50 students. The application was applied in the academic year of 2008 - 2009. The average duration of application is a lesson. Data collection tools have been applied in the classroom by classroom teachers. The investigator met with teachers and students in the schools which were made the application. The investigator arranged to teachers meeting in order to give information about the work. The investigator interviewed with students, visited to classes, he was found in the classroom during the application. Applications have been made under the leadership of teachers. Kendall's W test was applied to determine compatibility between assessments of three different expert for 15 students. A result of this survey, a significant alignment was seen between the experts statistically (W: $0.88, \mathrm{p}<0.01$ ). 50 students selected randomly from students who learned first reading and writing with the sentence method. The scoring criteria of answers which were given by these students is as follows:

Accurate and descriptive answer: 2 points, right and the short answer: 1 point, no answer or wrong answer: 0 points.

The result of the survey, the points of mean, frequency and percentage were calculated in the analysis of datas which were collected to determine level of reading comprehension of students who learned first reading and writing with the sentence method. Statistics were performed using program SPSS.

\section{Findings}

The findings and reviews which were derived from the survey in accordance with the data collection tools were examined as two separate headings. 


\subsection{The answers of Quantitative (Frequency, Percentage)}

Table 1. The percentage and frequency analysis of the answers which were given in the part of multiple-choice questions by students who learned first reading and writing with the sentence method

\begin{tabular}{ccccc}
\hline \multirow{2}{*}{ Questions } & \multicolumn{2}{c}{ Sentence Method (SM) } & Wrong Answer \\
& $f$ & $\begin{array}{c}\text { Right Answer } \\
\%\end{array}$ & $f$ & 0,353 \\
\hline 1 & 640 & 0,64 & 353 & 0,147 \\
2 & 850 & 0,85 & 147 & 0,382 \\
3 & 610 & 0,61 & 382 & 0,091 \\
4 & 904 & 0,904 & 91 & 0,178 \\
5 & 812 & 0,812 & 178 & 0,203 \\
6 & 792 & 0,792 & 203 & 0,156 \\
7 & 835 & 0,835 & 156 & 0,052 \\
8 & 937 & 0,937 & 52 & 0,489 \\
9 & 503 & 0,503 & 489 & 0,158 \\
\hline
\end{tabular}

The question which the highest success is shown by students who learned first literacy with the sentence method in the part of multiple-choice of the achievement test is eighth question. $(\% 0,937)$.The reason of student's high success fort this question can be to stated the answer of question clearly in the text.

The question which the lowest success is shown by students who learned first literacy with the sentence method in the part of multiple-choice of the achievement test is ninth question. (\% 0,489).The reason of student's failure can be these matters; the answer of question isn't specified clearly in the text, the students need to use the high level thinking skills to reach the answer, the students need to establish the logical relationship using the information of text. The most blank question is tenth question by students who learned first literacy with the sentence method in the part of multiple-choice of the achievement test. $(\%$ 0,013).The reason of this state can be these matters; the attention of students decreased because of last question, the degree of difficulty of this question is higher than others. The average accounts of the answer which were given to the part of multiple-choice of the achievement test by students who learned first reading and writing with the sentence method are as follows:

The percentage of the correct answer is $77,12 \%$. The percentage of the wrong answer is $22,09 \%$. The percentage of the blank answer is $0,79 \%$. The success $100 \%$ is ideal in the reading comprehension. 77,91'lik \% percent is considered good. It can be said students were already successful in the part of multiple-choice questions in reading comprehension.

\subsection{The Answers of Qualitative (Frequency, Percentage)}

Table 2. The percentage and frequency analysis of the answers which were given in the part of the open-ended questions by students who learned first reading and writing with the sentence method

\begin{tabular}{cllllrr}
\hline \multirow{2}{*}{ Questions } & \multicolumn{2}{c}{2 points } & \multicolumn{2}{c}{1 point } & \multicolumn{2}{c}{0 point } \\
\hline Q 1 & $f$ & $\%$ & $f$ & $\%$ & 4 & 8 \\
Q 2 & 22 & 44 & 24 & 48 & 2 & 4 \\
Q 3 & 25 & 50 & 23 & 46 & 14 & 28 \\
Q 4 & 10 & 20 & 26 & 52 & 45 & 90 \\
Q 5 & 5 & 10 & 2 & 4 & 21 & 42 \\
\hline
\end{tabular}

The question which the highest success is shown by students who learned first literacy with the sentence method in the part of open-ended of the achievement test is second question $(0,50 \%)$. The reason of student's high success fort this question can be to stated the answer of question clearly in the text and to be an easy question. The question which the lowest success is showen by students who learned first literacy with the sentence method in the part of open-ended of the achievement test is third question (52\%). The reason of student's failure can be these matters; the answer of question isn't specified clearly in the text, the students need to use the high level thinking skills to reach the answer, the students need to have analysis, synthesis and evaluation skills.

The most blank question is fourth question by students who learned first literacy with the sentence method in the part of open-ended of the achievement test $(90 \%)$. The reason of this state can be these matters; the degree of difficulty of this question is higher than others, the students must make inferences reaching from the abstract information to concret, they must have the ability to make generalization.

The average accounts of the answer which were given to the part of open-ended question of the achievement test by students who learned first reading and writing with the sentence method

The percentage of the correct answer is $34 \%$.The percentage of the wrong answer is $22,09 \%$. The percentage of the blank answer is $32,4 \%$. It can be said the students were unsuccesful in the open-ended questions. The students have 
experienced difficulty in expressing themselves. It can be said students have a insufficient writing skills. The reason of this state the teachers give priority to the multiple-choice test while they making the measurement and assessment. The vocabulary of students, their expression skills haven't developed, the students don't have make daily habit of writing activities as essay, story, letter, etc.

\section{Discussion}

The results of study which was made to determine the level of reading comprehension of students who learned first reading and writing with the sentence method are as follows:

The percentage of the correct answer to 10 multiple-choice questions is $77,12 \%$. The percentage of the wrong answer to 10 multiple-choice questions is $22,09 \%$. The percentage of the blank answer to 10 multiple-choice questions is $0,79 \%$.It can be said the students are succesful.

The percentage of the correct answer to 5 open-ended questions is $34 \%$. The percentage of the wrong answer to 5 open-ended questions is $22,09 \%$. The percentage of the blank answer to 5 open-ended questions is $32,4 \%$.

The students are succesful in the multiple-choice questions. In line with research findings this study are found in the literature:

Temizkan and Sallabaş (2011) compared the open-ended essay with multiple choice tests in the assessment of the student's reading comprehension. By this study, the students are successful in the multiple - choice tests in terms of reading comprehension. Turan and Akpinar (2008) concluded that reading comprehension and sentence analysis method is more effective in terms of speed reading by views of teacher in their research which were examined the reasons for prefering the sound based sentence method and sentence method. By Kadığlu (2012), teachers saw as a positive side of the sentence method to reading comprehension and speed-reading. According to the findings of research, it can be seen that students who learned first reading and writing eith the sentence method are successful in terms of the reading comprehension.

In line with research findings this study are also found in the literature:

Tok and Mazı (2008) examined to make meaningful and quick reading with the sentence method in the teaching of first reading and writing.

There are many ways of reading comprehension. Only one method may be insufficient. To make discussions, to use projects and performance tasks, to print text, to ask questions, to make presentations, to prepare books, to make the group work etc ... it is some of the methods used. When open-ended questions are asked, the answer key should be prepared so that include a wide range. The answer key which includes multiple possibilities will contribute to be valid and reliable measuring. The right of taking the wrong option can be put to work to eliminate the possibility that right by accident of the multiple-choice tests in the steps that are required a high level logical operations. So the different set out between knowing and unknowing. Creativity of test type of multiple choice questions is in the negative of these types of tests that measure the ability of the composition. The logic of marking to any matter which is read to students can be considered as a disadvantage because the students don't use the high level considering skills. The combination of multiple choice and open-ended questions is important in terms of measurement of reading comprehension. The teachers of elementary school should help to develop student's reading comprehension skills using the development strategies of reading comprehension skills (read before, during and after) in all the courses of expression and skills. To summarize to read, print questions as homework, to produce the individual specific questions from the text, to make the main idea work may take place between the methods which can be used by teacher in the class. The most important method is to ask questions too measure reading comprehension. To use often asking question skills, these skills are used by students can help to develop student's this skill. The effect of level understanding of this method can be measured to be passed the sound based sentence method. The effects of level understanding of methods are determined by measuring the level understanding of students who learned first reading and writing with the different methods. The factors that are effect to reading comprehension are determined by using the views of classroom teachers and Turkish teachers. The researchers are made by taking attention to the factors that are effect to reading comprehension (number of books read, newspaper reading frequency, education status of parental, course of Turkish). The each species questions must be in the test that is selected as the measurement tool. To prefer multiple-choice questions, open-ended questions and to fill the blank is disponible.

\section{References}

Aktaş, N. (2015). Before read the effect of the teaching of strategie on the forth classe's student's reading comprehension level from the monitör (Unpublished Master's Thesis). University of Gazi, Institute of Educational Sciences, Ankara. 
Akyol, H., Yıldırım, K., Ateş, S., Çetinkaya, Ç., \& Rasinski, T. V. (2014). Assessment of Reading. Ankara: Pegema Publishing.

Belet, D., \& Yaşar, Ş. (2007). The effect of the Teaching Strategies to Attitudes toward The Reading Comprehension and Writing Skills and Turkish Course. Theory and Practice in Education. 3(1), 69-86.

Çelenk, S. (2007). Teaching of Reading and Writing in the Light of Modern Teaching Approach. Editor: Ayla Oktay, Özgül Polat Unutkan. Education Area. İstanbul: Morpa.

Çiftçi, Ö., \& Temizyürek, F. (2008). The Measurement of Fifth Grade Student's Reading Comprehension. University of Mustafa Kemal.The Journal of the Institute of Social Sciences, 5(9), 109-129.

Creswell, J. W. (2012). Educational Research, Pearson Education, Inc., Boston, MA.

Demirel, Ö. (2002). Art of Teaching from Plan to Assessment. Ankara: PegemA Publishing.

Ekiz, D., Erdoğan, T., \& Uzuner, F. G. (2012).The Development of The Reading Comprehension Through The Action Research. The Journal Of Academic Social Science Studies, 5(7), 303-328.

Güleryüz, H. (2000). Theory and Practice of the Programmed Teaching of First Reading and Writing. Ankara: Pegema Publishing.

Işık, A. E. (2014). The Investigation of Development of Reading and Writing Skills of Students who began the school at 60-66 months of age (Unpublished Master's Thesis). University of Uşak, The Institute of Social Sciences: Uşak.

Kadıŏlu, H. (2012). The Investigation of The Skills of Italic Handwriting, Speed and Attitude of Elementary First Grade Students, Şenyıldız: İstanbul.

Kayalan, M. (2000). The Art of Effective and Fast Reading. İstanbul.

Kuşdemir, K. B., \& Karabay, A. (2012). Study On Reading Comprehension Skills Of Primary School 5th Grade Students-Learning Basic Reading And Writing Skills Through Phonics-Based Sentence Method Or Decoding Method. The Educational Sciences in the Theory and Practice, 12(2), 2854-2860.

Kutlu, Ö., Yıldırım, Ö., Bilican, S., \& Kumandaş, H. (2011). The Investigation of the Factor that Affect to Determine The Success of Fifth Grade Students in the Reading Comprehension. The Journal Of Measurement and Assessment in the Education and Psychology, 2(1), 132-139.

Kutluca, C. A. (2013). Effectiveness of School Support Education (Unpublished Master's Thesis) University of Abant İzzet Baysal The Institute of Educational Sciences, Bolu.

Özdemir, E. (1983). The Art of Reading . İstanbul: Varlık Publishing

Özder, H., Konedralı, G., \& Doğan, H. (2012). The Assessment of Fifth Grade Student's Reading Comprehension Skills. The Journal of International Curriculum and Instruction. 1, 3.

Şahin, A. (2011). The Comparison of the Level of Comprehension and the Speed of Read of the Students who Learned First Reading and Writing with the Different. The Journal of University of Hacettepe's Educational Sciences. 41, 423-433.

Şahin, İ., İnci, S., Turan, H., \& Apak, Ö. (2006).The Comparison of The Sound Based Sentence Method and The Sentence Method in the First Reading and Writing. Ministry of Education, 171, 109-129.

Soysal, T. (2015). The Effect of the Speed Reading on the Speeds of read and the Level of Comprehension of Fifth Grade Students (Unpublished Master's Thesis) University of Abant İzzet Baysal, Institute of Educational, Bolu.

Taşdemir, M. (2010). The Study on the Relationship between the Strategies of Comprehension and the Success in the Use of the. The Journal of Turkish Educational Sciences, 8(4), 913-947.

Tazebay, A. (1997). The Effect of Elementary School's Students's Reading Skills on the Reading Comprehension. MEB: Ankara.

Temizkan, M., \& Sallabaş, M. E. (2011).The Comparison of the Multiple-choice tests and the Open-ended Questions in the Assessment of Reading Comprehension Skills. The Journal of Liberal Arts of Dumlupinar, 30, 207-220.

Tok, S., Tok. T. N., \& Mazı, A. (2008).The Assessment of the Sentence Method and the Sound Based Sentence Method in the Teaching of First Reading and Writing. Journal of Educational Administration in Theory and Practice, 53,123-144.

Topuzkanamış, E., \& Maltepe, S. (2010). The Level of the Candidates of Teacher's Reading Comprehension and Use of Reading Strategies. TÜBAR-XXVII, 655-677. 
Turan, M., \& ve Akpinar, B. (2008).The Assessment of the Sound Based Sentence Method and the Method of Italic Handwriting in Turkish. The Journal of Liberal Arts of University of Firat, 18(1), 121-138, Elazı $\breve{g}$.

Ünal, E., \& ve Köksal, K. (2007). The Reading Comprehension and Questions. University and Society: The Journal of Science, Education and Opinion, 7(4), Aralık 2007. http://www.universite-toplum.org

Ürün, K. B. (2015). The Relationship of Attitude and Motivation Against Reading of 5th and 6th Grade Students with Reading Comprehension (Unpublished Master's Thesis) Institute of Educational Sciences of University of Atatürk, Erzurum.

Vatansever, H. (2008). The Assessment of the Success of the Students who Learned First Reading and Writing with Sentence Method and Sound Based Sentence Method. (Unpublished Master's Thesis). Institute of Educational Sciences of University of Marmara, İstanbul.

Yllmaz, M. (2008). The Way of Reading Comprehension Skills in Turkish. The Journal of Liberal Arts of University of Mustafa Kemal, 5(9), 131-139.

Yılmaz, M., \& Ağırtaş, M. N. (2009). The Assessment of Sound Based Sentence Method in the First Reading and Writing by Views of Teachers Example of Town Hatay. The Journal of Liberal Arts of University of Mustafa Kemal, 6(12), 164-175.

\section{(oc) BY}

This work is licensed under a Creative Commons Attribution 3.0 License. 